\section{Znaczenie odczuwane: projekt interpretacji relacyjnej}

Agnieszka Dauksza

TEKSTY DRUGIE 2016, NR 4, S. 265-281

DOI: 10.18318/td.2016.4.18
Tekst powstałw ramach grantu finansowego ze środków Narodowego Centrum Nauki przyznanych na podstawie decyzji numer DEC-2013/11/N/HS2/03509. Autorka artykułu została wsparta finansowaniem Fundacji na rzecz Nauki Polskiej (FNP). ednym z istotniejszych pożytków płynących ze studiów afektywnych jest dowartościowanie relacyjności.To, co sytuuje się „między”, „wobec”, ,obok” i pobudza dynamikę poruszeń, zarazem wyznacza kierunek prowadzonych badań. Afekt, choć aspołeczny, nie jest prespołeczny, cyrkuluje „na styku ciał” (Massumi'), dynamicznie kształtuje relacje między jednostkami i grupami (np. Reddy, Stearnsowie, Leavitt, Leys ${ }^{2}$ ), podlega transmisjom $\left(\right.$ Brennan $\left.^{3}\right)$, a także funkcjonuje między ludzkim i nie-ludzkim (np.

1 B. Massumi Autonomia afektu, przeł. A. Lipszyc, „Teksty Drugie” 2013 nr 6, s. 118.

2 W.M. Reddy Przeciw konstruktywizmowi. Etnografia historyczna emocji, w: Emocje w kulturze, red. M. Rejtar, J. Straczuk, przeł. M. Rajtar, Narodowe Centrum Kultury, Wydawnictwa UW, Warszawa 2012; P.N. Stearns, C. Stearns Emocjonologia: objaśnienie historii emocji i standardów emocjonalnych, w: Emocje w kulturze; J. Leavitt Znaczenie i czucie w antropologii emocji, w: Emocje w kulturze; R. Leys From Guilt to Shame: Auschwitz and After, Princeton University Press, Princeton 2007.

3 T. Brennan The Transmission of Affect, Cornell University Press, Ithaca-London 2004.

\section{Agnieszka Dauksza}

- w Katedrze An-

tropologii Literatury

¡Badań Kulturowych

WP Uj przygotowuje

pracę doktorską

poświęconą afektom

w literaturze i sztuce

modernizmu.

Autorka książek:

Kobiety na drodze.

Doświadczenie

przestrzeni publicznej

w literaturze przełomu

XIX iXXwieku (2013)

oraz Klub Auschwitz

i inne kluby. Rwane opowieści przeżywców

(w druku). Kontakt:

agnieszka.dauksza@

gmail.com 
Gibson, Johnson ${ }^{4}$. Jednostkowe intensywności znajdują wydźwięk w szerszych, społecznych ramach oddziaływania „ekonomii afektu" (Ahmed ${ }^{5}$ oraz we współwystępujących lub antagonizujących wspólnotach emocjonalnych i afektywnych (Rosenwein, Gandhi ${ }^{6}$ ). Interakcje i pobudzenia wywierają z kolei wpływ na równoprawne, sprawcze aktanty, czyli triadę twórcy-odbiorcy-dzieła (Nader7), co znajduje oddźwięk w synestetycznej percepcji i recepcji. Afektywne związki zachodzą zresztą nie tylko między bytami materialnymi, ale też między pojęciami $\left(\mathrm{Bal}^{8}\right)$, formami ekspresji (Berlant, Armstrong, Bennett $\left.{ }^{9}\right)$ czy dziedzinami i dyscyplinami $\left(\mathrm{Gregg}^{10}\right)$. U podstaw tak zakrojonych badań leży kwestia komplementarności funkcjonowania binaryzowanych dotąd aparatów i mediów poznawczych (np. Damasio"11). Okazuje się zatem, że zwrot afektywny nie jest zwrotem ku afektowi jako trudnej do zbadania, abstrakcyjnej kategorii, lecz zwracaniem się ku źródłom i przekaźnikom tego, co porusza, a więc współobecnym i namacalnym jednostkom i zbiorowościom, zjawiskom natury i obiektom kultury, obrazom i narracjom. Oczywiście nie można powiedzieć, że te napięcia i relacje nie bywały niegdyś przedmiotem namysłu, jednak z pewnością często je marginalizowano, określając je zbiorczo mianem „kontekstu”.

Chciałabym upomnieć się właśnie o to, co pozornie kontekstowe. Czy możliwe jest efektywne połączenie nierozłącznych, a nie, jak zwykło się

4 J.J. Gibson The Ecological Approach to Visual Perception, Hillsdale, New York 1979; M. Johnson Znaczenie ciała. Estetyka rozumienia ludzkiego, przeł. J. Płuciennik, Wydawnictwo UŁ, Łódź 2015.

5 S. Ahmed Ekonomie afektywne, przeł. M. Glosowitz, "Opcje” 2013 nr 1/2.

6 B. Rosenwein Obawy o emocje w historii, przeł. J. Wysmułek, "Teksty Drugie” 2015 nr 1; tejże Emotional communities in the early Middle Ages, Cornell University, New York 2007; L. Gandhi Affective Communities. Anticolonial Thought and the Politics of Friendship, Permanent Black, Delhi 2006.

7 L. Nader Afektywna historia sztuki, „Teksty Drugie” $2014 \mathrm{nr} 1$.

8 M. Bal Wędrujące pojęcia wnaukach humanistycznych. Krótki przewodnik, przeł. M. Bucholc, Narodowe Centrum Kultury, Warszawa 2013.

9 L. Berlant Cruel Optimism, Duke University Press, Durham-London 2011; I. Armstrong Myślenie afektu, w: Pamięć i afekty, red. Z. Budrewicz, R. Sendyka, R. Nycz, przeł. A. Kowalcze-Pawlik, T. Bilczewski, Wydawnictwo IBL PAN, Warszawa 2014; J. Bennett Empathic Vision. Affect, Trauma, and Contemporary Art, Stanford University Press, Stanford 2005.

M. Gregg Cultural Studies'Affective Voices, Palgrave MacMillan, New York 2006.

11 A. Damasio /ak umysłzyskałjaźń. Konstruowanie świadomego mózgu, przeł. N. Radomski, Rebis, Poznań 2011. 
przyjmować, rozłącznych narracji „emocjonalnych” i „intelektualnych”? Szukając inspiracji w istniejących koncepcjach, podejmuję wstępną próbę obnażenia słabych stron, uproszczeń i generalizacji tradycyjnych teorii interpretacji stwierdzających przede wszystkim erudycyjno-kompetencyjny sposób recepcji. Postuluję istnienie kilku faz czy etapów odbioru wykraczających poza "czysto" intelektualne procedury, lecz z nimi nieantagonizujących, a także przekonuję o szerszym, również pozaestetycznym wymiarze takiego modelu. Ważny jest dla mnie relacyjny charakter procesów poznawczych, które - jak postaram się udowodnić - zależą wprost od wspólnot emocjonalnych.

\section{Historie równoległe?}

Barbara Rosenwein, uzasadniając zróżnicowanie historycznych wspólnot emocjonalnych, przytomnie zauważa, że zgodnie z zasadą kontroli emocji i „zarządzania sercami” „to, co ludzie myślą o uczuciach, będą też czuli”12. W konsekwencji „historia intelektualna staje się kluczem do zrozumienia historii uczuć, nie zaś jej przeciwieństwem"13. Powstaje pytanie, czy do pomyślenia jest analogiczna metoda w odbiorze literatury i sztuki: ponad- czy podtekstowe/podobrazowe rejestrowanie tego, co w przeszłości kształtowało postawy i determinowało wybory? Wydaje się - zgodnie z transmisyjno-wrażeniową logiką - że do pewnego stopnia jest to nie tylko możliwe, ale także efektywne, gdyż ludzkie oceny oraz wyobrażenia indywidualnych i społecznych wymiarów wrażliwości determinują sposoby odczuwania, a także opis procesów poznania, interpretacji i doświadczenia.

Można zresztą dostrzec paralele między historycznymi zmianami dominujących języków opisu interpretacji i sposobami ujmowania tego, co emocjonalne. W tradycyjnych systemach emocje uznawano za nietożsame z rozumem siły uwięzione w ludzkim ciele, co według Rosenwein wynikało z logiki "hydraulicznego" modelu, zgodnie z którym „emocje są niczym potężne płyny zamknięte w ciele człowieka, falujące i spieniające się, gotowe do wydostania się na zewnątrz", a „korzenie tego modelu wywodzą się w dużym stopniu ze średniowiecznej medycznej koncepcji humorów"14. Hydrauliczna metaforyka oraz irracjonalny charakter emocji były coraz intensywniej negowane od

\footnotetext{
12 B. Rosenwein Obawy o emocje w historii, s. 363.

13 Tamże, s. 382.

14 Tamże, s. 378.
} 
lat 6o. XX wieku, gdy kognitywiści wyróżnili grupy determinowanych biologicznie emocji podstawowych, uznając, że pełnią one integralną funkcję w procesach percepcji i oceny. Konstruktywiści z kolei dostrzegali kulturową zmienność norm odczuwania i bezpośrednią zależność kształtowania emocji od języka, praktyk kulturowych, oczekiwań i przekonań, w konsekwencji stwierdzając złożony, społeczny charakter tego, co emocjonalne.

Z zastaną metodą opisu cyrkulowania emocji korespondowały „hydrauliczne" modele poznawczego oscylowania między powierzchnią i głębią oraz zewnętrzem i wnętrzem danego komunikatu, odczytywania czy rozszyfrowywania zakodowanych „na dnie" lub zdeponowanych „w środku” przekazu sensów, zasadniczo tożsame dla ujęć „nowokrytycznych”, fenomenologicznych, hermeneutycznych i strukturalistycznych. W tym układzie dzieło rozumiane jest jako twór autonomiczny, zamknięty i spójny. Aż nadto upraszczając, lektura jawi się jako akt mediowania między tym, co jawne i odkryte, i tym, co schowane czy ukryte, jako sprawdzian kompetencyjny z biegłości i przenikliwości rozwiązywania zagadek tekstowych, któremu może sprostać „modelowy” czytelnik $\left(\mathrm{Eco}^{15}\right)$. Znaczenie „powierzchniowe” jest więc przesłoną dla zdeponowanego w dziele, ,immanentnego" sensu czy, jak u Ricœura - „poziomy znaczeniowe” zawierają się w „znaczeniu dosłownym” odszyfrowywanym dzięki pracy myślowej ${ }^{16}$.

W kontrze do tych modeli lokuje się poststrukturalistyczna koncepcja dzieła jako procesualnego, zmiennego, podatnego na oddziaływanie odbiorcy splotu, tkaniny (Barthes), patchworku czy pajęczyny (N.K. Miller), rozrastającej się i łączliwej hybrydycznej konstrukcji (Deleuze). Choć stanowiska poszczególnych badaczy poststrukturalizmu są różne, bardzo generalizując, można stwierdzić, że odrzucona zostaje dialektyka powierzchni i głębi dzieła, a znaczenie jest relacyjną cechą wypracowywaną, uzgadnianą, nanoszoną czy przemocą narzucaną w silnie ukontekstowionym akcie interpretacji. Lektura opiera się na inwencji znaczeniotwórczej samego odbiorcy (J.H. Miller) lub na kontekstowym użyciu tekstu (Rorty), jest odbiorczym eksperymentem (Deleuze), polem panowania polityki i władzy (Rancière) czy uzgadnianym wspólnotowo konstruowaniem sensu (Fish).

Według Marka Johnsona konsekwentnie podtrzymywana dychotomia poznawczego/emocjonalnego w teorii nowoczesnej „doprowadziła w końcu

U. Eco Interpretacja i nadinterpretacja, red. S. Collini, przeł. T. Bieroń, Znak, Kraków 1996.

P. Ricœur Egzystencja i hermeneutyka, Rozprawy o metodzie, oprac. S. Cichowicz, przeł. E. Bieńkowska i in., De Agostini, Warszawa 1975. 
do wykluczenia emocji i odczucia z uprzywilejowanej domeny znaczenia poznawczego i z opisowych użyć języka, zwalniając tym samym filozofów z konieczności dostarczenia opisu uczucia w ramach ich teorii znaczenia"17. Ponowoczesne rozpoznania bezpośrednio nie przełamały tego impasu, zwykle bowiem praca lektury miała polegać na intelektualno-praktycznym używaniu tekstu - zawsze przy wykorzystaniu określonych kompetencji i w konkretnym kontekście. Jednak chodziło przede wszystkim o usytuowanie czytelnika/widza rozpatrywane z perspektywy historycznej, instytucjonalnej, politycznej, klasowej czy genderowej, niekoniecznie przez pryzmat nadawczo-odbiorczych wrażliwości, pobudzeń, wrażeń i emocji.

\section{Doświadczenie lektury}

Jedną z prób przekroczenia konkurencyjnych teorii odbioru jest koncepcja Ryszarda Nycza przekonującego, że dzieła są „współkonstytuowane znaczeniowo przez pracę interpretacji i doświadczenie lektury”, a w efekcie projektują i „eksperymentalnie testują ramy, na które same są odpowiedzią"18. Akt poznawczy, lektura sama w sobie, jest nie tylko intelektualnym, ale także afektywno-zmysłowym doświadczeniem, bez którego nie mogłoby dochodzić do otwarcia na inność tekstu i w konsekwencji do jego zrozumienia. Proces odbioru składa się z trzech istotnych faz: „przedinterpretacyjnej”, która jest doświadczeniem rozumienia wykraczającym poza intelektualne przypisywanie znaczeń, co jest możliwe dzięki „osadzeniu wypowiedzi w kontekście podzielanych przez wspólnotę afektywno-doznaniowych doświadczeń". Chodzi tu o spontaniczność i szybkość rozumienia „ramowego”, bez specyfikacji poszczególnych znaczeń ${ }^{19}$. Dopiero niemożność identyfikacji, wrażenie obcości, niezrozumiałości czy niejasności prowokuje do podjęcia czynności interpretacyjnych, które - w przypadku powodzenia - prowadzą do "poszerzenia świata własnego dyskursu w rezultacie przyswojenia (rozszyfrowania, przełożenia) dotąd niezrozumiałego" ${ }^{20}$. Dopełnieniem tych procesów jest doświadczenie czytania pojmowane jako „uwewnętrznienie”

17 M. Johnson Znaczenie ciała..., s. 72.

18 R. Nycz Poetyka doświadczenia. Teoria - nowoczesność - literatura, Wydawnictwo IBL PAN, WarSzawa 2012, s. 304. 
dzieła i jego rozumienia, uczynienie z dzieła jednocześnie „instrumentu i medium poznania". Teoria ta warta jest uwagi choćby ze względu na otwarcie na perspektywę doznaniowo-afektywną oraz niejednowymiarowe pojmowanie dynamicznych zależności między odruchami, odczuciami, dążeniami, kompetencjami i uwikłaniami jednostki w akcie odbioru.

Koncepcja uświadamia redukcjonistyczny charakter wielu modeli intelektualnego poznania, co mogłyby z kolei stanowić pretekst do zradykalizowania stanowiska i postulowania trybu lektury afektywnej. Czym miałaby ona być? Termin nie jest jednoznaczny, gdyż dałoby się nim zapewne określać zarówno przedintelektualne fazy percepcji, jak i akty interpretacji wykorzystujące metody studiów afektywnych, a także lekturę tekstów kultury określanych jako "afektywne” z powodu sposobu ich organizacji, tematyki, cech formalnych czy wywoływanych przez nie „efektów obcości”. Jednak podobne sposoby rozumienia nie są wystarczające. W istocie chodzi bowiem o przekroczenie dualizmu afekt-intelekt i zaproponowanie takiego trybu interpretacji tekstów i zjawisk, który w równej mierze uwzględniałby pełnoprawne i niemożliwe do oddzielenia afektywne i intelektualne możliwości ludzkiego poznania współkonstytuujące powstanie każdego znaczenia. Dlatego z tej perspektywy „interpretacja afektywna” wydaje się zbyt wąskim pojęciem.

\section{Interpretacja relacyjna}

Punktem wyjścia jest stan, który Jean-Luc Nancy określa jako „teoretyczny nadmiar (a ściślej, nadmiar względem tego, co teoretyczne)", czyli „coś” wyraziście odczuwalnego, lecz opierającego się wyraźnej identyfikacji. Nancy określa taki moment jako „miejsce komunikacji”, w którym faktycznie:

istnieje coś, nie zaś nic: nasza granica i nasze ograniczenie zawierają się w tym, iż tak naprawdę nie mamy nazwy dla tego czegoś lub kogoś. [...] $\mathrm{z}$ braku nazwy musimy uaktywnić słowa, aby ponownie wprawić w ruch granicę naszego myślenia. W miejscu komunikacji nie istnieje ani podmiot, ani komunijny byt, lecz wspólnota i dzielenie. ${ }^{21}$

Chodzi zatem o granice naszego rozumienia - to, co odczute jako nie-swoje, nowe i obce, sprawia trudności poznawcze, gdyż ani percepcja, ani

21 J.-L. Nancy Rozdzielona wspólnota, przeł. M. Gusin, T. Załuski, Wydawnictwo Naukowe Dolnośląskiej Szkoły Wyższej, Wrocław 2010, s. 37. 
natychmiastowe rozumienie nie przynoszą wymiernych efektów, nie zachodzą machinalnie, wymagają wysiłku i zaangażowania jednostki. Niemożność zrozumienia wiąże się z problemem nazwania, ponieważ - co oczywiste każda interpretacja bazuje na elementarnych kompetencjach językowych, erudycyjnych, doświadczeniowych i kulturowych, które są w istocie kompetencjami wspólnoty. Coś, co zdaje się pochodzić spoza kręgu pojmowanego jako „wspólny”, wzbudza odruchowy opór.

Okazuje się zatem, że każda konfrontacja z czymś, co niezrozumiałe, jest zarazem dotarciem do granic - własnych, ale i własnej wspólnoty. Próba zrozumienia wymusza poruszenie, interpretacja to - jak chce Nancy - „wprawianie w ruch granicy naszego myślenia”. Zakładam, że dotyczy to każdego aktu interpretacji, a więc próba zrozumienia właściwie dowolnego przedmiotu estetycznego i pozaestetycznego składa się z kilku nietożsamych odczuciowo-racjonalizujących etapów. Co za tym idzie, w procesie odbioru używane są nie tylko kontekstowe i wspólnotowe kompetencje, ale też między trzema aktantami procesu: autorem, dziełem i odbiorcą zawiązywane są wspólnoty komunikacyjne. Dlatego proponuję wyjście poza kategorie interpretacji pojęciowej i rozważenie perspektyw interpretacji relacyjnej.

Gdy piszę o próbie wyjścia „poza interpretację pojęciową”, nie sugeruję oczywiście zanegowania czy odwrotu od teorii racjonalnego charakteru procesu odbiorczego. Chodzi mi jednak o traktowanie go nie jako jedynego wymiaru interpretacji, lecz jednego z jej komplementarnych komponentów. To ujęcie przynosi zasadnicze korzyści, gdyż pozwala zredefiniować standardowe procedury interpretacji, rozszerzyć jej zakres o tradycję afektywno-doświadczeniową i o przedpojęciowe formy wspólnotowych ram rozumienia/odczuwania.

Proponując model interpretacji relacyjnej, jestem skłonna wyróżniać kilka faz procesu odbioru, jednak mam świadomość, jak upraszczający jest opis w istocie niepodzielnych pasm mikrozdarzeń i momentalnie, niemal symultanicznie zachodzących neurobiologicznych zjawisk - nieustanne wyczuwanie myśli i myślenie czucia. Wydaje się, że najpierw dochodzi do sensorycznego i synestezyjnego rejestrowania, „wyczuwania” danego obiektu, podejmowana jest też próba konfrontowania go z tym, co znajome, i „rozpoznania" przez pryzmat znanych kategorii. Wiąże się to z wypracowywaniem tymczasowych znaczeń odczuwanych.

Brian Massumi przedstawia te procesy jako „tajemnicę brakującej połowy sekundy"22. Filozof, komentując przebieg i wyniki eksperymentu medycznego, 
w którym za pomocą elektroencefalografu badano fale mózgowe ochotników, stwierdza, że istnieje trudny do sprecyzowania półsekundowy interwał reakcji. Wszystko wskazuje, że nie jest on jednak „pusty”, lecz „przepełniony właśnie wykonywanym działaniem i przypisywanym mu znaczeniem”, a świadomość działa wówczas jako siła redukująca „złożoność nazbyt bogatą, by można ją było wyrazić w sposób funkcjonalny" ${ }^{23}$. Mark Johnson z kolei - za Johnem Deweyem - utrzymuje, że początkowo można mówić o odczuwaniu "niezanalizowanej masy”, „całościowego przytłaczającego wrażenia”, dominującej, ,nierozkładalnej” jakości, z której są następnie wyróżniane poszczególne obiekty, własności i relacje $\mathrm{e}^{24}$.

Znaczenie odczuwane - określane też jako „protoznaczenie” lub „znaczenie-w-procesie" - to przedrefleksyjny, zjawiający się niemal natychmiast w reakcji na dane przeżycie, intuicyjny i przedwerbalny „zalążek myśli”, jak nazywa je Claire Petitmengin ${ }^{25}$. Zwykle dochodzi do pojawienia się na powierzchni świadomości niejasnego, niekiedy rozmytego, a kiedy indziej nader intensywnego wrażenia, najczęściej transmodalnego, będącego pewnym amalgamatem, w którym odczucia poszczególnych zmysłów nie są jeszcze zniuansowane; podobnie wnętrze i zewnętrze oraz podmiot i przedmiot są wciąż nieodróżnialne. Dopiero ta wstępna faza byłaby początkiem procesu różnicowania, rozgraniczania obiektów, kształtowania myślowych obrazów, uczuć i pojęć, nakierowujących myślenie konceptualne. Co istotne, przedrefleksyjna mikroaktywność powstawania znaczenia odczuwanego jest złożonym, najczęściej nieuświadamianym, lecz w gruncie rzeczy bardzo zwyczajnym, bazowym procesem powtarzanym chwila po chwili. Pozostaje on aktywny nawet wówczas, gdy wyłania się z niego znaczenie pojęciowe, z którego powstają słowa, obrazy, pomysły czy idee. Niewygaszenie tego potencjału decyduje zapewne o przeczuciu istnienia wciąż oddziałującej „resztki” czy „nadwyżki” znaczeniowej oraz o wrażeniu niepełnej adekwatności form ekspresji do tego, co chce się wyrazić26.

23 Tamże, s. 118.

24 M. Johnson Znaczenie ciała..., s. 94.

25 C. Petitmengin Ku źródłom myśli. Gesty itransmodalność: wymiar przeżywanego doświadczenia, przeł. E. Bodal, A. Tuszyński, „AVANT” 2012 nr 3.

Akapit jest zmienioną wersją fragmentu rozważań publikowanych w innym artykule, A. Dauksza Przemoc wrażenia. Wstępne rozpoznanie literatury i sztuki afektywnej, w: Kultura afektu afekty w kulturze. Humanistyka po zwrocie afektywnym, red. R. Nycz, A. Łebkowska, A. Dauksza, Wydawnictwo IBL PAN, Warszawa 2015. 
Według Massumiego jest to kluczowa dla pracy afektu „przestrzeń fazowa”, w której psychocielesny system „obejmuje liczne i zazwyczaj wzajemnie wykluczające się możliwości, z których tylko jedna zostaje wybrana"27. W tym „momencie krytycznym” angażowane są różne poziomy: „umysł i ciało, lecz także wola i poznanie, porządki języka, oczekiwanie i napięcie, wnętrze i powierzchnie ciała, przeszłość i przyszłość, spokój i pobudzenie"28. W przekonaniu Massumiego nie są to binarne opozycje, lecz relacyjne i rezonujące obszary, a „afekt jest ich punktem wyłonienia, w ich faktycznej specyfice, w osobliwości, w ich wirtualnej koegzystencji i wzajemnym powiązaniu to ich punkt krytyczny towarzyszący jak cień każdemu obrazowi/ekspresji-wydarzeniu"29. Fazowość, polisensoryczność i nierozstrzygalność znaczenia odczuwanego zostaje zresztą przemieszczona "na poziom myśli”, co - jak sugeruje Massumi - „ilustruje dekonstruowalność wszelkiej struktury idei” wyrażonej np. w Derridiańskiej zasadzie différance ${ }^{30}$.

Sens pojęciowy rzadko wyłania się w precyzyjnej, skończonej formie. Co więcej, racjonalizacja zachodzących procesów nie jest procedurą wyłącznie intelektualną, gdyż wyraźnie czerpie z fazy poprzedniej - rezerwuaru pierwszych odczuć, wrażeń i intuicji. Niemniej Mark Johnson utrzymuje, że tylko te znaczenia odczuwane, które zostają świadomie przyswojone, okazują się dla odbiorcy znaczące ${ }^{31}$. Tworzą się w ten sposób znaczenia pojęciowe, które w kognitywistyce są niekiedy określane jako „konceptualne”, „intelektualne” lub „abstrakcyjne”.

Zdaje się, że to właśnie ten etap poznania przedstawień wizualnych Georges Didi-Huberman określa jako „ruch wyłaniania się z morza, w którym to, co było zanurzone, wyłania się z morza na chwilę, by zaraz ponownie zniknąć. To materia informis, kiedy dopasowuje się do przedstawienia, to wizualność, kiedy dopasowuje się do widzialności" ${ }^{\prime 2}$. Zapewne poszukiwanie odpowiedniości między złożonym, dynamicznie przekształcającym się odczuciem znaczenia i jego werbalną czy wizualną reprezentacją pozwala znajdować liczne,

B. Massumi Autonomia afektu, s. 121.

Tamże.

Tamże.

Tamże, s. 125.

M. Johnson Znaczenie ciała..., s. 43.

G. Didi-Huberman Przed obrazem. Pytanie o cele historii sztuki, przeł. B. Brzezicka, słowo/obraz terytoria, Gdańsk 2011, s. 99. 
nieraz konkurencyjne warianty interpretacyjne. Jeśli dane zjawisko zostaje zakwalifikowane przez aparaty poznawcze jako rozpoznawalne, możliwe do pojęcia dzięki zapisanym strukturom doświadczenia i przy użyciu znanych kategorii, wówczas rozumienie zachodzi machinalnie. Tak dzieje się np. z wyrażeniami z języka potocznego, które w akcie komunikacji niejako natychmiast „nabierają sensu”, gdyż zdają się „neutralnymi, stylistycznie nienacechowanymi stwierdzeniami, po prostu odnoszącymi się do czegoś, lub po prostu o czymś komunikującymi"33. Stanley Fish podważa oczywistość takiego rozumienia, proponując zastosowanie do podobnych wypowiedzi pytania ,jak to działa?” oraz sugerując, że każde, nawet pozornie najbardziej błahe „doświadczenie językowe oddziałuje i wywiera pewien nacisk, choć w przeważającej części odbywa się to w takim zbliżeniu, na tak podstawowym, przedświadomym poziomie doświadczenia, że na ogół tego nie zauwa-

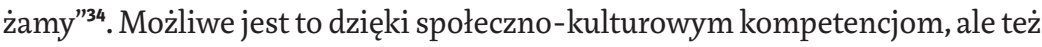
dzięki współuczestnictwie we wspólnotach emocjonalnych, o czym szerzej za chwilę.

Niepowodzenie „natychmiastowego”, bezwiednego rozumienia inicjuje procesy interpretacyjne. Opór poznawczy nie wynika jednak ze stopnia skomplikowania danego dzieła, lecz raczej z charakteru reakcji odbiorczej. Nie analizuje się przecież rzeczy samych w sobie, ale własne percepty i odczucia. Trudność zrozumienia danego zjawiska wynika zatem z niemożności zastosowania gotowego scenariusza poznawczego i łatwego sklasyfikowania konfrontacji. Niejednoznaczność tego stanu powoduje, że etap wypracowania znaczenia odczuwanego przestaje być bezwiednym, ignorowanym przez świadomość etapem i urasta do rangi rejestrowanego, intensywnego stanu. Afektywne poruszenie czytelnika/widza wytrąconego ze schematu odbiorczego jest analogiczne do spotkania jednostki z czymś, co inne, obce, nieznane, niewpisujące się w wyobrażenie wspólnoty. Nierozstrzygalność bywa odczuwana jako efekt obcości. Afektywne zakłócenie opisuje Didi-Huberman, stwierdzając, że jeśli nie rozumie się, „wtedy rozumie się mimo wszystko, rozumie się coś z sedna tego sporu, co paraliżuje myślenie"35. Afektywność nie jest immanentną cechą sztuki czy literatury. Afekt może być

33 S. Fish Literatura w czytelniku: stylistyka afektywna, przeł. M. Fedewicz, „Pamiętnik Literacki”, 1983z. 1. 
jednak objawem czy skutkiem oddziaływania na odbiorcę. Mechanizm zależy od zintensyfikowania bodźców, dziwności czy oryginalności dzieła, choć te właściwości nie mają decydującego znaczenia. Istotny jest za to przebieg i charakter konfrontacji z widzem/czytelnikiem oraz sposób działania danego tekstu kultury na konkretnego odbiorcę w określonym kontekście.

Prawdopodobnie dopiero w kolejnym etapie, następującym po wypracowaniu znaczeń pojęciowych, dochodzi do twórczego rozwiązywania znaczeniowych problemów dzieła, zajmowania estetycznego stanowiska, przyjmowania emocjonalnej postawy względem dzieła, budowania logicznej argumentacji, uwewnętrzniania dystynktywnych cech opisywanego przedmiotu, słowem - świadomego doświadczania procesu odbioru i tworzenia się pewnej gotowości do reprezentowania tego doświadczenia. Ekspresja jawi się z tej perspektywy jako urzeczywistnienie pola dotychczasowych możliwości i zarazem jako „wygaszenie” afektywnej intensywności znaczenia odczuwanego ${ }^{36}$. W konsekwencji okazywałoby się, że zarówno komponent odczuciowo-afektywny, jak i intelektualny, są nieodłącznymi, pełnoprawnymi elementami procesów poznawczych w ogóle, niemożliwymi do odseparowania i świadczącymi zarówno o ponaddualistycznej strukturze ludzkiego aparatu poznawczego, jak też sugerującymi taki właśnie charakter artystycznych realizacji.

Pozostaje jednak pytanie, dlaczego określam ten tryb odbioru mianem interpretacji relacyjnej? Istotnych jest kilka aspektów terminu „relacja” rozumianego zarówno jako opis przebiegu jakiegoś zdarzenia, jak i zależnośćl styczność obiektów oraz związek między jednostkami lub grupami. Chodzi mi głównie o następujące kwestie: 1. interpretacja - jako narracja aktu lektury - przybiera postać relacji z procesu interpretowania, 2. interpretacja opiera się na korespondowaniu jej poszczególnych faz i poziomów, 3. przedstawienia są nieodmiennie odbierane przez pryzmat ich relacyjnych powiązań z konstelacyjną siecią innych tekstów czy obrazów, 4. każde znaczenie jest wielostopniową relacją.

Interpretacja relacyjna - z gruntu procesualna - czyni metodę z relacjonowania swego przebiegu. Uważność lektury idzie w parze z włączeniem do analizy opisu doświadczenia odbioru. Siłą rzeczy interpretacje relacyjne są zazwyczaj studiami przypadków, jednak nie tylko omawiają unikalne obiekty, ale także proponują specyficzne języki analizy i nowe siatki pojęciowe. Zdawanie relacji z doświadczenia interpretacyjnego często wiąże się więc 
z bardziej uniwersalną propozycją inwencyjnej metody recepcji tekstów kultury.

O relacyjności interpretacji można mówić także na poziomie zależności między cielesno-biologicznymi, odczuciowymi i intelektualnymi zdolnościami poznawczymi - zarówno pobudzanymi w bieżących aktach odbioru, jak i odtwarzanymi ze „śladów minionych działań wraz ze śladami ich kontekstów zachowanych w mózgu i ciele"37. Kolejny poziom wyznaczają zróżnicowane, lecz wchodzące w interakcje, multisensoryczne czy transmodalne bodźce i poruszenia, których korespondencja stopniowo zmienia kształty znaczeń, co zasadniczo potwierdza tezę, że całościowe rozumienie jest „sumą wszystkich naszych interakcji" ${ }^{\prime 3}$. Sugeruje to także angielskie, dwuznaczne słowo sense wskazujące elementarną zależność między czuciem, zmysłami, rozumem i znaczeniem. Jeśli zatem traktować percepty i pojęcia jako „różne gatunkowo aspekty ciągłego przepływu czucio-myślenia" ${ }^{39}$, okaże się, że każde znaczenie jest wartością relacyjną.

\section{Znaczenie relacyjne a wspólnoty emocjonalne}

Proces lektury, wchodzenie w interakcję odbiorcy i dzieła, to zatem tyleż konfrontowanie zróżnicowanych właściwości i kompetencji intelektualno-kulturowych, niemożliwy do rozwikłania splot uwarunkowań kontekstowych, ile wydarzenie o charakterze afektywno-doświadczeniowym. Rzecz jasna, istotne są też - co zresztą udowadniała Mieke Bal - związki między konstelacyjnymi, „wędrującymi” pojęciami oraz artystycznymi i literackimi konwencjami, wymiarami intertekstualności i korespondującymi dyscyplinami. Niemniej każdorazowe aktualizowanie tych potencjałów decyduje dopiero o przebiegu, randze i odczuciowo-poznawczych efektach aktu interpretacji.

Rozumienie uzgadniane jest w wielostopniowym procesie, niemniej trzeba pamiętać, że żadna tego typu interakcja nie przebiega w izolacji. Relacyjny charakter znaczenia nie zależy bowiem wyłącznie od integralności aparatów i poziomów procesu poznawczego, ale też od ponadjednostkowego kontekstu, który - choć jest niekiedy uznawany za „zewnętrzny” w stosunku do poznającej jednostki - w istocie nie tylko ją „otacza”, ale także współtworzy i określa

Tamże, s. 118.

B. Tuchańska Ontologia kulturowa: kulturowość bycia „ "Diametros” 2014 nr 42, s. 12. 
jej normy odczuwania, zachowania i myślenia. Barbara Tuchańska, dialogując z tezami Martina Heideggera, postuluje „kulturowość wszelkiego bycia” i jednocześnie wskazuje na dwuaspektowy charakter każdego znaczenia zawierający się w jego odniesieniu i sensie. Co ważne, te dwa aspekty znaczenia, „które jedne byty mają dla innych bytów" ${ }^{\text {" }}$, znajdują odpowiedniość nie tylko między praktycznymi i komunikacyjnymi „wzajemnościami” jednostek, ale też we wspólnocie i między wspólnotami:

Ontologia kulturowa pozwala także rozpoznać wspólnotowy charakter znaczenia. Z perspektywy ontologicznej znaczenie (znaczeniowość) jest warunkiem wspólnotowych systemów interpretacyjnych i normatywnych, które uczestniczą we wszelkich rodzajach wspólnotowej aktywności, kształtując i normując jej przebieg. [...] Szczególną rolę w kształtowaniu praktyk odgrywają wartości, które są ontologicznym warunkiem wspólnotowych systemów normatywnych oraz instytucji społecznych (zwyczajów usankcjonowanych), i tym samym stanowią warunek ich obowiązywania. W takiej mierze, w jakiej systemy interpretacyjne i normatywne są w praktykach wspólnotowych konstytuowane i zmieniane, modyfikowane są także odniesienia, sensy i wartości bycia. ${ }^{41}$

Znaczenie zyskuje status „wspólnotowy”, gdyż jest podstawą funkcjonowania systemów rozumienia i oceny, na których opiera się każda wspólnota. Rozumienie z kolei - co zresztą można wyczytać już u Arystotelesa - możliwe jest dopiero na kanwie podzielanych wartości, choć nie bez znaczenia są wspólne wyobrażenia, fantazmaty, emocje i sposoby reakcji.

Zakładam, że podobnie jak nowoczesne struktury narodowe fundowane są nie tyle na więziach fizycznych, ile na wyobrażeniach relacji, tak procesy rozumienia zależą przede wszystkim od poczucia wspólnotowości - osadzenia w kontekście, oddziaływania wspólnot interpretacyjnych, zakorzenienia w systemie symbolicznym itd..$^{42}$ Co za tym idzie, wspólnoty wyobrażone społeczne, ale i odbiorcze - opierają się na jakościach emocjonalnych, niekoniecznie czy nie zawsze pozytywnych - możliwe są wszakże reakcje niechęci,

B. Tuchańska Ontologia kulturowa.., s. 268.

Tamże, s. 274. obrażone. Rozważania o źródłach i rozprzestrzenianiu się nacjonalizmu, przeł. S. Amsterdamski, Znak, Fundacja im. Stefana Batorego, Kraków-Warszawa 1997. 
wstrętu, niezgody. Tym samym wszelkie wspólnoty wyobrażone są zarazem współwystępującymi, dialogującymi, komplementarnymi, antagonizującymi czy konkurującymi wspólnotami emocjonalnymi ${ }^{43}$. Rosenwein, uzasadniając ich funkcjonowanie, argumentuje:

To na pierwotnych więziach, które wytworzyły emocje, powstały języki, idee i instytucje ludzkiej cywilizacji, lecz emocje pozostały oddzielone od kultury, którą same stworzyły. [...] emocje nie były częścią cywilizowanego życia, chociaż były niezbędne dla jego istnienia. ${ }^{44}$

\section{Z kolei Fryderyk Nietzsche przekonywał:}

słowa są znakami pojęć: pojęcia zaś są mniej lub bardziej bezpiecznymi grupami powracających, zbiegających się odczuć. Żeby zrozumieć, nie wystarczy jeszcze posługiwać się tymi samymi słowami: tych samych słów trzeba użyć do tego samego rodzaju wewnętrznych przeżyć - i muszą być wspólne. ${ }^{45}$

Co najmniej kilka wątków domaga się sprecyzowania, ale tymczasem istotne jest dla mnie podkreślenie, że być może, wbrew pierwszym intuicjom, najważniejsza nie jest tu kwestia łatwości komunikowania się (porozumienia bez słów, intuicyjnego rozumienia) jednostek czy wspólnot, które łączą wspólne doświadczenia kulturowe. Wielce prawdopodobne, że Nietzschemu nie chodzi tylko o istnienie uprzedniej, np. kulturowej wspólnoty połączonej stałym intuicyjnym i przedwerbalnym porozumieniem. Podobnie jest zresztą z odbiorczymi „paktami”. Owe wspólne wewnętrzne przeżycia mogą równie dobrze być efektem konfrontacji oddziałującej realizacji artystycznej i ulegającego temu oddziaływaniu odbiorcy. W tym ujęciu dzieło wytwarza pole napięć i energetycznych potencjałów, z którymi może współreagować

43 Rosenwein następująco definiuje wspólnoty emocjonalne: „są one dokładnie tym samym, co wspólnoty społeczne [...], jednak studiujący je badacz dąży przede wszystkim do odkrycia ich systemu uczuć: tego co te społeczności (i jednostki w ramach nich) określały i osądzały za wartościowe lub szkodliwe; oceny, które wystawiały wobec emocji innych; uznawana przez nich natura istniejących między ludźmi więzi afektywnych; oraz formy ekspresji emocjonalnych, których oczekiwali, do których zachęcali, które tolerowali, i nad którymi ubolewali", por. tejże Obawy o emocje w historii, s. 385-386. 
odbiorca. Praca artystyczna stwarza więc sposobność do przeżywania, jest zapalnikiem doświadczenia interpretacyjnego. Tak rozumiane doświadczenie estetyczne jest nie tyle, czy nie tylko, momentem potwierdzenia uprzedniej wspólnotowości, ile okazuje się momentem powstania takiej relacji (czemu może oczywiście sprzyjać wspólny krąg kulturowy). Wydaje się również, że czytelniczy/estetyczny pakt jest podstawą każdego transferu odczuć i znaczeń oraz staje się niezbywalnym czynnikiem umożliwiającym zrozumienie. W dodatku ten rodzaj zależności nie musi polegać na porozumieniu, zgodzie, wypracowaniu konsensusu itd. Powstawanie odbiorczych wspólnot może się równie dobrze opierać na odrzuceniu, wyparciu czy konflikcie interesów. Nie jest tu bowiem istotne powodzenie aktu czy „spajanie" perspektyw triady odbiorczej. Chodzi raczej o wstępną relację, utworzenie przestrzeni wymiany czy przepływu wrażeń i znaczeń, a także - choćby negatywne - elementarne zainteresowanie, które przecież ma swój źródłosłów w łacińskim interesse, czyli "byciu pomiędzy” - interakcji twórcy, dzieła, odbiorcy.

O ile prawdą jest, że różne rywalizujące ze sobą kultury, także emocjonalne, można dostrzec nie tylko w danej społeczności, ale też w jednym, tym samym odbiorcy ${ }^{46}$, o tyle z pewnością zdarza się, że podobne antagonizmy określają relację między dziełem i jego odbiorcą, decydują o dynamice procesu interpretacji, pozwalają dostrzec wielość możliwych odczytań lub, przeciwnie - zaciemniają pole postrzegania.

Łatwe, niemal odruchowe podzielanie wartości albo, z drugiej strony, antagonizowanie z jakościami reprezentowanymi przez przedmiot poznania, zawsze jest rodzajem mniej lub bardziej fortunnej próby emocjonalno-kulturowego transferu, nawiązania łączności z cudzym doświadczeniem. Jeśli jednak myślenie pojawia się nie gdzie indziej, jak właśnie na granicy ${ }^{47}$, to zapewne tylko za sprawą jej przekroczenia lub poruszenia czymś odmiennym lub nowym, przez wytworzenie różnicy potencjałów, może dojść do zmiany struktur odczuwania i myślenia. Opór poznawczy wytwarza więc miejsce różnicy i podziału. Nie bez przyczyny Nancy zakłada, że „w miejscu komunikacji nie istnieje ani podmiot, ani komunijny byt, lecz wspólnota i dzielenie"48 , a także za Georges'em Bataille'em stwierdza: „Nie może być poznania bez wspólnoty ani doświadczenia wewnętrznego bez wspólnoty tych, którzy

\footnotetext{
46 B. Rosenwein Obawy o emocje w historii, s. 386.

47 J.-L. Nancy Rozdzielona wspólnota, s. 37.

48 Tamże, s. 33.
} 
nim żyją" 49 i dalej: „być może nie jest ono czymś, czego po prostu doświadczamy, lecz raczej stanowi doświadczenie, dzięki któremu jesteśmy"50.

Projekt interpretacji relacyjnej nie zakłada utopijnej wiary w spoistość czy trwałość wspólnotowego bycia; chodzi o fakt nieodzowności i nieuchronności wyobrażeniowego odnoszenia się do tego, co wspólne, dzielone lub osobne - na poziomie interpretacyjnym, ale - co za tym idzie - egzystencjalnym. Teza Nancy’ego głosi, że „jednostkowy byt zjawia się jako sama skończoność, u krańca (lub u początku), w kontakcie ze skórą (albo z sercem) innego jednostkowego bytu, na granicy tej samej jednostkowości, która jest, jako taka, zawsze inna, zawsze dzielona, zawsze wyeksponowana"51. Stwierdzenia te pozwalają argumentować, że jednostkowość wydarza się jedynie „wobec” kogoś lub czegoś, w komunikacji pojmowanej jako sensotwórcza interakcja. Skoro więc świadome bycie jest możliwe wyłącznie przez interpretację i w interpretacji, a każda praca rozumienia jest przekraczaniem granic odczuwania i doświadczenia odbiorcy, to skłaniające czy prowokujące do wysiłku interpretacyjnego dzieła są dzianiem się sensów. Relacyjność tego procesu zawiera się zarówno w polisensorycznym i afektywno-racjonalnym charakterze odbioru, jak i w umocowaniu każdego aktu interpretacji w tym, co wspólnotowe $\mathrm{i}$ intertekstualne, oraz $\mathrm{w}$ wielostopniowej zależności interpretującego i interpretowanego. Z kolei owo „interpretowane” - jak sugerował niegdyś Stanley Fish - „nie jest już obiektem, rzeczą-samą-w-sobie, lecz zdarzeniem, czymś, co się przydarza czytelnikowi i w czym bierze on udział. I to właśnie zdarzenie i jego przebieg - jego całość, a nie cokolwiek, co dałoby się o nim powiedzieć, czy jakakolwiek informacja, jaką można by z niego wydobyć jest, jak twierdzę, znaczeniem"52.

\footnotetext{
49 Tamże.

50 Tamże, s. 38.

51 Tamże, s. 40 


\section{Abstract}

\section{Agnieszka Dauksza}

JAGIELLONIAN UNIVERSITY (CRACOW)

Sensed Meaning: The Project of Relational Interpellation

Dauksza proposes the model of relational interpretation and postulates the existence of several phases or stages of reception. She discusses the simplifications and generalizations of traditional theories of interpretation, which serve above all to assert the reader's erudition and competence. While the phases of relational interpretation postulated here go beyond purely intellectual procedures, they do not go as far as becoming antagonistic towards them. The point is to overcome the dualism of affect and intellect, and to propose a mode of interpretation that takes into account both affective and intellectual possibilities of cognition. Among the categories analysed is that of sensed meaning. Dauksza also describes the relationality of each meaning and the relational nature of interpretive processes, which depend on emotional communities in both the cultural and the social sense.

\section{Keywords}

interpretation, affects, emotional communities, sensed meaning 